\title{
Europe and the Political: From Axiological Monism to Pluralistic Dialogism
}

\author{
Richard Sakwa
}

\section{Abstract}

'The political' represents a moment in which actors recognise autonomy and equality as constitutive values in the agonistic search for appropriate open-ended political outcomes. In today's power struggles, the tutelary, pedagogical and disciplinary practices of the depoliticised European Union (EU) undermine the foundations of equality in diplomatic and political engagement between continental actors. The relationship tends to become axiological, where issues are deemed to have been resolved through some sort of anterior pre-political arrangement. Solutions to the historical problems of one era and situation are transferred as complete and finished answers to the challenges of other times and spaces. This is a type of ahistorical political monism that ultimately claims to speak for all of Europe. The return of 'the political' would allow a more generous and pluralistic politics to emerge based on genuine dialogical foundations in which self and other engage as equals and are mutually transformed by that engagement.

Keywords: monism, finalité, the political, dialogism, European Union, Russia.

\section{Introduction}

The European post-Cold War order has assumed monist forms. ${ }^{1}$ Instead of the geopolitical and ideological diversity sought by Mikhail Gorbachev as he brought the Cold War to an end in the late 1980s, a type of monist cold peace was imposed in which Atlanticist institutions and ideas were advanced as the only appropriate ones. Even traditional Gaullist Euro-Atlantic aspirations were marginalised, and even more so Gorbachevian aspirations for a 'Common European Home' (today known as the greater Europe project). This monological response by definition excluded Russia as anything but subaltern in the post-communist European peace order. An axiological style of politics predominated where negotiation reduced to discussion of the terms of adaptation rather than an open-ended dialogical relationship of mutual engagement and transformation. The European Union (EU) from the outset had a monist potential, which in the post-Cold War era became an actuality. The bureaucratic political character of the EU distanced politics from the demos, undermining popular sovereignty (Heartfield 2013). While societies and states in the EU are intensely plural, there has been a monist, non-political, character to the EU's development. This is amplified when it comes to external relations. The EU has been monist externally in the sense that it projects a certain vision of the world and represents a certain type of European order. This is the substance of the debate about the EU as a normative power. For Europe, the past was the other, the struggle to repudiate and transcend the cycle of inter-state conflicts that culminated in two devastating world wars in less

\footnotetext{
${ }^{1}$ This article was originally conceived as part of a project on 'The Politics and "The Political" of the Eastern Partnership Initiative: Re-shaping the Agenda', directed by Elena Korosteleva. I would like to thank her, as well as my other colleagues at the University of Kent, Eske Van Gils and Igor MerheimEyre, for their support, help and comments.
} 
than half a century (Wæver 1996). The result, paradoxically, was incoherence in dealing with the actual spatial others on the EU's borders to the east. Having achieved a certain resolution of its own temporal challenges, the EU proved unable to devise equally effective solutions to the spatial challenges on its periphery.

The response was to transform the continent in the EU's image. The EU represents a type of 'smaller Europe', a core in which certain problems of history have putatively been resolved. The 'wider Europe' project seeks to apply this resolution to a 'frontline' area with a very different history, contested identities and specific regional challenges. The temporal linearity of the transitological approach assumed a spatial character, characterised by conditionality, 'external governance', and 'downloading'. The intersection of time and space had potentially devastating consequences. Through the practices of 'Europeanisation' the region was to be transformed through enlargement and neighbourhood policies. The result in the case of Ukraine was the catastrophic breakdown of the post-Cold War European security order (Sakwa 2016). This provoked what some call a new 'Cold War' (Cohen 2017, Legvold 2016), whose causes remain contested. One argument is that the original Cold War never ended, since the institutions and ideological framework in which it was instantiated on the western side continued to exist and flourish. From this perspective, Europe never really managed to crawl out from the Cold War overlay, and the notion of a Europe 'whole and free' became just another axiological slogan of the Atlantic hegemony. Another view suggests that the new confrontation in Europe is so different that the appropriation of the concept of 'Cold War' represents an abuse of history and a misunderstanding of the dynamics of renewed contestation (Monaghan 2015). There are many more contrasting interpretive frameworks, but what is uncontested is that we are now faced with contending axiologies (deep-rooted ontologies of social reality), each of which is relatively hermetic. Interactions between these axiological systems operate at the normative, identarian and geopolitical levels and assume depoliticised forms.

In defence of the prerogatives and primacy of the 'smaller Europe', the EU failed to substantiate a transformed European community in which valance was given to the political subjectivity of the other. For understandable reasons, the EU feared exposing itself to relationships that were not one-directional but open to dialogical engagement in which both sides were susceptible to transformation by the act of engagement itself. This would politicise the relationships, and allow a shift beyond a monism based on the idea that political problems have already been resolved, and all that remains is to transfer these solutions to the EU's environs. Instead, in its Eastern neighbourhood, the EU practiced a politics of enlargement without accession, driven by the agenda of norm and policy diffusion. The incentive structure for the recipients was by no means geared so favourably to the EU as it was in most of the countries of Central and Eastern Europe in the enlargements of the 2000s (Edkins (ed.) 1999). A technocratic politics-as-usual oriented approach generated contradictions that ultimately can only be resolved by the return of the political as an act of agonistic negotiation between ontological equals (Mouffe 1993). Following the shock of the Ukraine crisis there is an increased awareness in the EU that the classic enlargement model has reached its limits and that a new approach is required. The response, however, has been more about a change in tone rather than in the substantive methods, and the old hierarchies have been maintained. Relations with others are still centred on reproducing the norms of the pre-established order through bureaucratised politics. The appropriate framework for the return of the political in the EU's engagement with its neighbourhood remains unclear, but the unfinished agenda of 1989 remains on the table - the radical transformation of European political space.

We do not need to look far to find the normative framework for a more political Europe. The pluralist 'greater Europe' advocated by Russia and some other countries represents an alternative ideational and normative representation of 'Europe', as well as providing a more 
'dialogical' alternative spatial 'architecture' for the continent. The advocacy of geopolitical and ideational pluralism at the European level means the return of the common search for the solution to historical problems of continental development. The return of history also means the return of the political. The smaller Europe represented by the EU in this framework becomes just one actor among many, while its 'wider Europe' agenda is subsumed into a broader debate over how to create a pan-European political community. Instead of the "clash of integrations' and 'competing neighbourhoods', the priority becomes the struggle to shape a European commonwealth. This is far from a return to the politics of Yalta, where the fate of the continent was decided by sovereign great powers. This is not only unacceptable to the smaller states, but the very idea of 'spheres of influence' is normatively hostile to a genuinely plural Europe. The substantive model of greater Europe represents precisely a framework where all the states and societies can express political diversity within a common framework of pan-European institutions (for a critique, see Zwolski 2016).

Instead, European monism as expressed in the smaller and wider Europes is a model of development unable to engage with difference on the basis of equality. In other words, European monism is the institutional expression of incorporated 'politics' where history has ended. Bureaucratic processes substantiate a Heideggerian techné, a specific technocratic approach to the management of public and international affairs. The classic Monnet-method was designed to depoliticise the integration process, but the neo-functionalist primacy of economics and politics over society and culture had devastating long-term consequences (Pabst 2016, 196). The technocratic imperative was at its most devastating after 1989. The EU was challenged to forge isomorphic political relations with neighbouring countries that could not be disciplined through the accession process. Instead of open-ended dialogue and pluralistic engagement between equal sovereignties characteristic of 'the political', the depoliticised policy of tutelary enlargement of the Atlantic system was practiced.

This article will move in five steps. The next section outlines the multiplicity of existing Europes, and analyses the stresses imposed on the plural reality by monist practices. This is followed by some theoretical discussion which seeks to deepen understanding of the contradictions of contemporary European spatial and normative order. The third section explores the historical roots of contemporary European monism, followed by discussion of monism and finalité, the debate about the meaning and purpose of the EU and its limits. The fifth and final substantive section brings us back to the present and the EU's response to the current crisis.

\section{Many Europes and none}

Three models of European spatial order are in contestation, each representing a certain type of politics. The smaller Europe represented by the EU asserts expansive normative and spatial claims, yet it is by definition partial and lacks an isomorphic continental agenda. It is naïve to assume that the EU's Atlanticist anchor has not influenced the formulation of policy to the post-communist East (pace Haukkala 2016). The normative framework has been the subject of extensive discussion, but has tended to establish the ideational framework for the parallel debate over the spatial dimension. The problem has been that these two debates have been conducted in parallel; when they come together, there are some disturbing theoretical consequences. The normative discussion describes the quality and character of the type of politics represented by the EU. When this is applied to spatial interaction, it provokes a hermetic discourse that assumes certain fundamental problems of interaction have been resolved. This shapes the debate over the second Europe, the one which is the object of the EU 'wider Europe' strategy. This is a zone of contestation, but the character of the struggle is peculiarly depoliticised. While there are extensive discussions of a technical character, the 
fundamental political issues are reduced to bureaucratic resolution. The mismatch between the technocratic practices of EU depoliticised governmentality and the region's heavily politicised struggles over identity generates a fracture zone reproducing the axiological and Gnostic politics of the Cold War era.

The third Europe is the one championed by Russia, namely the 'greater Europe' ideal of a continental union of some sort stretching from Lisbon to Vladivostok. Greater Europe, of course, is not a proprietary Russian idea, but has deep roots in European political philosophy. In the contemporary period, greater Europe is associated in particular with Charles de Gaulle's idea, advanced in Strasbourg on 23 November 1959, for a Europe from the Atlantic to the Urals, accompanied by what he later called a 'Europe des Patries'. In current parlance, this repudiates any moves towards a United States of Europe in favour of a Union of the States of Europe. This was the idea advanced by Gorbachev. Addressing the Council of Europe in Strasbourg on 6 July 1989, Gorbachev outlined his idea for a 'Common European Home' and his vision for post-Cold War Europe. Gorbachev argued eloquently and forcefully that different systems could coexist peacefully. Now commonly described as 'greater Europe', this is a programme for geopolitical and normative pluralism. The idea was taken up by Vladimir Putin from the mid-2000s, having failed to find a formula for Russia to become part of an extended Euro-Atlantic or EU community. The obvious paradox is that Russia's advocacy of a pluralistic conception of Europe is accompanied by the establishment of a distinctive type of monist depoliticisation in domestic politics. The mismatch undermines not only the credibility of the greater Europe project, but above all the willingness of partners to invest in a project that carries so many dangers of normative dilution and counter-hegemonic challenges to Atlanticist predominance. However, greater Europe is far more than a Russian project, and represents a way out of the strategic impasse in which the continent finds itself. It represents a specific mode of repoliticisation in which spatial and temporal transformative projects are combined. Given the obvious travails of the smaller Europe and the dangers of axiological conflict in the wider Europe, greater Europe is the potential framework for a new politics of continental reconciliation. Greater Europe has been stymied by the hegemonic dominance of Atlanticism in the post-Cold War years, but it is not incompatible with a Euro-Atlantic perspective, where institutionalised Gaullist continentalism becomes a structural partner and leadership is shared with the US.

These three Europes are in contention, but the debate between the contrasting perceptions of international order that they represent remains strangely disembedded from contemporary theoretical debates. This is particularly evident when it comes to the wider Europe, lacking a substantive and coherent political subjectivity of its own (a point I shall return to below). The EU is today typically portrayed as a post-modern entity committed to a post-Westphalian agenda of universal values, accompanied by a commitment to a set of normative principles (Cooper 2003). These norms are the basis for the EU's conditionality in dealing with external actors and its neighbours. Internally, the EU has assumed the characteristics of a neo-medieval polity, with overlapping jurisdictions and no settled sovereign centre (Zielonka 2007). It has a 'fuzzy' identity, like Russia itself, with both structured around what Laclau and Mouffe (2001) call the 'absent totality'. Although Russia is usually portrayed as having a strong sovereign centre, its identity is also in flux and is deeply variegated (Khazarski and Makarchev 2015). Externally, the EU has assumed an increasingly hard spatial configuration in recent years. Its external borders are mostly governed by Schengen regulations, allowing a single visa to operate across the participant countries, although the pressures of refugee and migratory flows from 2014 prompted a wave of suspensions and wallbuilding (Sakwa 2016). It is still too early to talk of a 'fortress Europe', especially in light of Germany's decision in 2015 to accept about a million refugees from Syria and other conflict zones, yet the crisis threw into sharp relief the tension between socio-economic and normative 
post-modernism and the securitisation of relations with the neighbourhood and the world. Time and space have come into collision.

This brought the once crucial but recently forgotten debate over finalité back into focus. This is the debate over the purpose and ends of the EU. Discussion of the purpose would restore elements of 'the political' to EU discourse, while debate over the ends would do the same about the limits to territorial expansion and the nature of the relationship to those in the liminal area across the border of the EU's furthest reaches. The political would be brought back in. Instead, the finalite debate has been overwhelmed by the multiple crises afflicting the EU. Instead of a substantive debate grounded in the political, discussion has tended to focus on the technocratic problem of saving the old politics. Already the struggle to save the euro has raised fundamental questions about the EU's identity, while the Brexit vote in the UK on 23 June 2016 provides another opportunity to return to the finalité debate. Discussion of what sort of Europe the peoples of the continent really want and not the one necessarily advanced by Europe's globalised elites is more than timely. As Laclau (2005) has argued, populist formulations can act as powerful articulations of suppressed political demands. From this perspective, populist assertions are not necessarily reactionary but can contain an emancipatory and progressive dynamic. This is the 'lexit' (exit from the EU from the left) debate stimulated by Wolfgang Streeck (2016).

The EU's enlargement into the wider Europe incorporates political cultures in much of the post-communist world for whom the simple idea of 'Europe' already represents the given solution to their problems. In other words, as far as many of these countries are concerned, there is little to gain from dabbling once again in the speculative sphere of utopian projects to build a progressive socialist, greater Europe, or other utopia, when their problems of history have already been putatively resolved by the EU. There is even less demand for a substantive central and eastern European assertion of a separate political identity. In other words, the lifting of the iron curtain dividing what Jozef Piłsudski in the inter-war years liked to call the 'intermarium' has not removed the region's peripherality. Instead, peripherality has been intensified, rendering the region a zone of contestation between powers that are centred elsewhere. The region has become a fragmentation zone of Europeanisation itself. 'Illiberal democracy' and conservative populism is generated in part by the pressures of peripherality. A Europe that was genuinely 'whole and free' would have seen Budapest or Warsaw become the capital of pan-European structures guiding the functional integration of the continent from Lisbon to Vladivostok, accompanied by the dialogical project for the emancipation of the continent from Cold War structures and ideas.

Instead, 'Europe' itself became the utopia of a peculiarly eviscerated and politically bloodless sort. The temporal aspiration for a more effective developmental model assumed a sharply delineated spatial configuration. Enlargement reinforced the death of the political and relegitimised the axiological politics of the present. Historical solutions that worked very well up to 1989 were mechanically applied to a very different post-Cold War context. With the multiple problems besetting the EU, it could become one more of the 'Gods that failed'. This is the bitter dilemma now facing Ukraine. Having staked so much on the European utopia, it finds itself in a peculiar dystopia of its own making. The Ukraine crisis was the ineluctable consequence of a depoliticised Europeanism that was unable to address fundamental problems of European security and community. Instead of an agonistic political debate about the finalite of Europe, in a syllogistic manner 'Europe' was presented as the depoliticised response to the crises of Europe.

Between axiological monism and pluralistic dialogue 
In the post-Cold War era European politics has taken on an increasingly axiological character. A monological approach, where substantive political questions are considered resolved in advance, generates a politics of closure in which certain fundamentals are considered axiomatic and not open to contestation. Conditionality is a politics of one-sided adaptation. The European method of development laid down by Jean Monnet explicitly sought to depoliticise certain issues, and functionalist approach that sought precisely to negate the political. The result was a distinctive type of monism. When it comes to the wider Europe, axiology reduced the scope for engagement with the political subjectivities of others. Axiological politics assumes that some things have been settled outside of the political process, and thus politics becomes a means for the implementation of a priori positions. Its ideological aspect assumes that answers have already been found to questions of human community. Politics become instrumental, and thus deprived of what many have argued is its agonistic essence: the organised and constrained struggle over fundamental matters of concern in the life of the community. Axiological politics denigrates the political subjectivity of actors, whether individuals, larger groupings or the entire state.

At the conceptual level, axiological politics can take several distinct, but typically interrelated, forms. Conspirology is one powerful form of axiological politics, based on victimhood and persecution by malign but often unstated forces. Populism is also typically characterised by an axiological dimension, with the stark contrast drawn between inherent popular wisdom and the trickery of elites. The notion of course is an ideal type, and public affairs will always contain an irreducible quotient of axiological politics. Nevertheless, the democratic ideal suggests that this can be tempered by the structured engagement of different political subjects in a 'communicative' process, as Jürgen Habermas (1984, 1987) has long argued. However, dialogical politics differs in some significant respects from Habermas's communicative interactions. First, it dispenses with the implicit hierarchy of relations in Habermas's theory, seen so notably in his discussion of post-secularism, where the views of the others are engaged because they exist, but are treated in a condescending manner (Ratzinger and Habermas 2007). In other words, the views of the other are to be respected, but essentially they are considered from the perspective of a superior us. Boundaries are reinforced and not challenged. Second, the communicative process is implicitly founded on the idea of settled identities, and thus the problem of liminality is not adequately integrated into the theory. In the case of Russia this is particularly important, since the country over recent decades has been engaged in an intense process of identity formation. It not a settled interlocutor but retains a deeply liminal character, which remains in flux and is torn by deeply contested representations of the ideal (Chebankova 2017).

Axiological politics stands in contrast, to borrow a term from Mikhail Bakhtin, with what can be called a dialogical process. The idea of dialogical politics seeks to shift attention from the institutional level, where executives will always seek to achieve axiological outcomes, and where legislatures also by definition engage in some sort of dialogical process, to more fundamental categories dealing with the quality of political relationships and various modes of engagement with the political process itself. This provides an ontology of European unity based not on the language of common values (although of course not repudiating these values), nor on a Realpolitik reversion to the language of interests (although not neglecting the creation of alliances based on the genuine commonality of concerns and operating through common practices of diplomacy), but rather on a common public sphere based on a dialogical process and a substantive idea of a European political community. In other words, it may be possible to escape from the crisis of European integration not by reverting to the traditional sovereignty of nation states but by moving forwards towards a pan-European pluralist identity.

This potentially provides a way out of the monological trap into which the EU and European politics in general have fallen. It would avoid the process where the EU sets itself up 
as a teacher to others (Prozorov 2016). The tutelary politics of the EU is particularly in evidence when dealing with the Eastern Partnership (EaP) countries, and this was one reason why Russia from the first refused to be part of the undifferentiated group of European Neighbourhood Policy (ENP) states. Instead, dialogism is politics that transcends the logic of incommensurable duality - the duality of the privileged self interacting through conditionality and tutelage with the other. It is thus a paradoxical politics, because dialogue assumes a conversation between at least two parties of recognised similar discursive status, and thus substantiates what is still to be established. It is the failure to resolve this paradox that has fostered a monistic relationship between the EU and non-EU others in the post-communist world. In the European context, it implies the creation of a substantive political community, with recognition of the validity of the political subjectivity of the interlocutor. It is ambivalence over the latter question that has bedevilled Russia's relations with the EU and the West since the end of the Cold War.

Since emerging as an independent state in 1991 Russia has tried to join the historical West as an equal partner. This is founded on Gorbachev's belief that the end of the Cold War provided an opportunity for the substantive transformation of European political community. The main institutions of the Atlantic system - the EU and the North Atlantic Treaty Organisation (NATO) - would in Russia's view become part of a greater Europe. Russia would join the historical West and thereby transform it into something else by virtue of its membership. What for Russia was considered a moment of expansion of the political, there was no need for such a dialogical relationship for the existing members of the old West, and instead administrative and normative enlargement substituted for a programme of transformation. There were genuine fears that opening the established Atlantic community to the political could dilute the normative and institutional framework of the existing order, but by closing down avenues for agonistic transformation, the community itself became increasingly stultified, and in the end even threatened its existence. The fate of the Soviet Union began to hang over the future of the EU and the Atlantic community as a whole.

The 'end of history' became the ideology of the death of the political. The postcommunist world, including Russia, was expected simply to adapt to the pre-established norms accompanied by the hierarchy of power in which they were embedded. For the established members of the 'historical West', the fall of the communist systems only revalidated the success of the old politics, and thus there was no need to engage in transformation or expose themselves to the dangers that would accompany the restoration of the political at the continental and global level. How can there be genuine dialogue where one side claims to have resolved certain problems of history and development, and the other side was heir to a system that had palpably failed? The post-Cold War settlement appropriated, to paraphrase Carl Schmitt, the concept of humanity (now designated as human rights). Schmitt $(1996,54)$ warned that 'whoever invokes humanity wants to cheat'. He warns of the political consequences: 'To confiscate the word humanity, to invoke and monopolize such a term probably has certain incalculable effects, such as denying the enemy the quality of being human and declaring him to be an enemy of humanity; and a war can thereby be driven to the most extreme inhumanity' (Schmitt 1996, 54). This is the ideational framework for a politics of enlargement, premised on conditionality and adaptation, accompanied by the suppression of the agonistic politics of transformation and renewal.

The anti-revolutions of 1989-1991 opened up the potential for a dialogical form of politics, once the axiological structures of the Cold War had been transcended. An 'antirevolution' is here defined as a political practice that not only repudiates a particular revolutionary cycle, but aims to transcend the axiological features of the revolutionary process (Sakwa 1998; Sakwa in Donald and Rees 2001). Instead, the following period was one of disappointment as new forms of axiological politics were imposed. The notion of the 'end of history' represented the closure of the political and the reinforcement of routine administrative 
politics. The agonistic search for new answers to new questions gave way to the reinforcement of a settlement that preceded the end of the conflict. Although the Helsinki follow-up conferences played an important part in bringing the Cold War to a negotiated end and provided the normative framework for the transformation of the conflict, the selective reification of the Helsinki Final Act of August 1975 (notably, its 'third basket' dealing with human rights) foreclosed debate. For the Kremlin, it came to be seen a way of imposing a power hierarchy which Russia increasingly found unacceptable. The anticipated openness of European geopolitics at the end of the Cold War was not accompanied by a commensurate dialogical negotiation of a new political settlement.

In the end, the perpetuation of the ideological and institutional structures of the Cold War gave rise to the cold peace (Sakwa 2013). Claims to sovereign equality were not matched by the substantive recognition of diversity and recognition of difference. European monism took the form of a 'civilising mission' (Zielonka 2013). Dialogue entails some sort of binary functionality, but it also requires respect for difference and thus some sort of methodological equality; a type of isomorphic unity created by a discussion between equals where the views of the interlocutor are respected and given equal weight. In a monological discourse, one of the parties (or both), considers itself normatively, and thus ontologically, superior to the interlocutor, and thus a series of mimetic relationships are established, including the process whereby one actor sets themselves up as teacher to the other. Contrary to the view that domestic politics shapes foreign policy, the post-communist era is characterised by the peculiar inversion whereby a country that pursues a monist policy at home calls for a pluralistic world order; while an EU that is intensely plural at home applies a monistic foreign policy.

\section{European monism}

The sources and configuration of contemporary European depoliticised monism take four main forms, here presented in schematic terms. First, the way that the Cold War ended, and ultimately the imposition of a triumphal 'victory' discourse on what had been assumed by the Soviet side to be a common victory. The turning point was the December 1989 Malta Summit, which brought Soviet leader Gorbachev and President George H. W. Bush together to decide the fate of Europe. The absence of a European leader highlighted Europe's subaltern status and failure to gain a substantive independent political subjectivity in the post-Cold War era. As at Yalta in February 1945, the great powers held the fate of Europe in their hands, but Malta registered the change in the diplomatic and strategic balance of power. Gorbachev understood that the Cold War stand-off between the Soviet Union and the Western powers served to undermine the development of both. With the end of the Cold War, it seemed that a new era of peace was at hand, reinforced by the reunification of the European continent. Gorbachev envisaged that the Soviet Union would remain a great power, but now one that worked cooperatively with the West. Later Russian leaders hoped to join the 'historical West' as an equal member, and thus create a 'greater West', the counterpart of greater Europe.

At Malta, Gorbachev tried to formalise a politics of transcendence that would overcome not just the historically contingent Cold War but herald an anti-revolutionary politics of reconciliation that would challenge the very structure of hegemonic power politics. In the event, the summit registered only a power shift within the framework of the politics of Yalta, but with a reversed polarity. The opportunity for a common victory was squandered. The conditions were created that ultimately exploded in Ukraine in 2014. The countries that had become the Soviet Union's unwilling allies later became the most enthusiastic supporters of Atlanticism. This only reinforced the axiological monism embedded in the politics of Malta. Instead of transcendence, a restated bloc politics reinforced the alleged victory of the West accompanied by the Atlantic overlay. This reinforced the axiological dynamic to the end of the Cold War, accompanied later by elements of Western triumphalism (despite enduring attempts 
to sweeten the bitter pill for Russia). For some these sweeteners, like the creation of the NATORussia Council, represented little more than appeasement and a failure to exploit Western victory (Kasparov and Greengard 2015).

Second, the Malta agreements built on the Helsinki Final Act and were codified in November 1990 in the 'Charter of Paris for a New Europe' and its ringing declaration of a 'Europe whole and free'. Helsinki had confirmed Yalta, above all the borders established in 1945 and the framework for the conduct of relations between the great powers, but at the same time Helsinki's human rights commitments provided a mechanism for the transcendence of Yalta. The paradox is that that Helsinki established a particular method for Yalta's transcendence, which itself ultimately proved corrosive of post-Cold War international relationships. In a Schmittian manner, E. H. Carr argued that the mix of idealism and realism in the interwar years proved fatal, preventing the exercise of traditional diplomacy while inhibiting realistic appreciations of the power consequences of one's own actions (Carr 2001). In other words, the established framework inhibited the exploration of new forms of engagement and differentiation through the political.

While the Soviet Union and Russia endorsed the principles inspiring the Charter of Paris, the perceived instrumental and selective application of these principles by the dominant powers created a situation in which the normal diplomatic intercourse between nations was distorted by normative agendas. The balance between 'regime transformers' and 'power balancers', currently labelled liberal interventionists and realists, was disrupted and allowed regime transformers to predominate (Goldgeier and McFaul 2003). Values in one way or another are an inalienable part of the currency of contemporary international relations, but diplomacy means that they are tempered by the pursuit of mutual interests. The radicalisation of the democratisation and human rights agenda by the Atlantic powers provoked a range of defensive reactions in Russia, which in the end weakened the democratic impulse. The idea of 'sovereign democracy' was only one manifestation of the search for an autochthonous balance between adaptation to international norms and the search for some sort of authentic native tradition to sustain post-communist political order. The problem can be couched in various ways, but in general terms it is a variant of the enduring tension between Enlightenment universalism and nativist particularism. It is also indicative of the tension between the monism of the axiological political style and the transformative pluralism of political dialogism.

The third determining factor shaping the cold peace and its ultimate degeneration into the so-called new Cold War is the failure of Europe to assume an independent political subjectivity. In his Strasbourg speech and later Gorbachev argued for the transcendence of Yalta and Malta. He sought to create a European form of international relations that encompassed the interests of both the small and great powers. This is a multipolar Europe with space for experimentation and diversity. The zone of intense integration in the EU would be just one element in the multiverse of a multipolar European architecture. Instead, the EU effectively claimed to be the sole legitimate voice of Europe, although in partnership with the more specialised Council of Europe and Organisation for Security and Cooperation in Europe (OSCE). The wider Europe project became part of the expansion of the broader Atlantic community. This is a monist vision of Europe, which cannot imagine any substantive alternative political, let alone ideational, alternative community. Just as liberalism in the postCold War era finds it hard to accept alternatives to its own hegemony, and thus erodes it own liberality (Horsfield 2017), so the Atlantic community failed to devise a form of engagement with outsiders that would mitigate rather than radicalise their outsiderness. In the case of Russia, the assumption that the way that historical problems had been resolved in one context were generically applicable to others was anathema. Even if a leadership in Russia were to accept this theoretical postulate (as it did to a large extent in the Boris Yeltsin years), the fact that historical problems of territorial unity, political identity, security cooperation, economic 
modernisation and international integration have still not been resolved means that tensions, if not conflict, would inevitably emerge.

Fourth, the failure to find an appropriate way for Russia and its neighbours to interact stimulated isolation rather than integration. Numerous earlier attempts to give institutional form to Eurasian integration in the post-Cold War years culminated in the creation of the Eurasian Economic Union (EEU) on 1 January 2015. This formalised the antagonism between two major integration projects, although the EEU was always intended to act as one of the pillars of greater Europe. The essence of the cold peace between 1989 and 2014 was the endless struggle between the great powers and the EU for influence in post-Soviet Eurasia. The final straw from Russia's perspective was the perceived attempt to wrest Ukraine away from Moscow's economic and security sphere. Zbigniew Brzezinski's argument in 1994 that 'It cannot be stressed strongly enough that without Ukraine, Russia ceases to be an empire, but with Ukraine suborned and the subordinated, Russia automatically becomes an empire' (Brzezinski 1994, 80) gave early warning of the stakes involved. Russian intervention in Ukraine in 2014 is perceived by the West to represent a violent challenge to the system of international law. However, from the Kremlin's perspective - and, it must be said, from the point of view of the great majority of Russian citizens - the struggle over Ukraine is considered to be a desperate last stand to defend not only Russia's interests but also that different vision of Europe's destiny expressed in the greater European ideal.

\section{Monism and finalité}

Decades of enlargement pushed the EU into uncharted territory, in both symbolic and political terms (Zielonka 2008). The expansionary dynamic through accession has now slowed, but there is no finalite in either spatial or normative terms. The EU remains an ambitious transformative agent in what are increasingly contested neighbourhoods (Rumelli 2004). The confrontation between the EU and Russia is one that neither wanted, and which both sought to avoid. The EU devised variegated neighbourhood policies to ensure that the outer limits of EU territory did not harden into new lines of division. Romano Prodi, the president of the European Commission, when introducing the ENP in Brussels on 5-6 December 2002 declared that 'I want to see a "ring of friends" surrounding the Union and its closest European neighbours, from Morocco to Russia and the Black Sea' (Prodi 2002). He went on to argue that this would encompass 'everything but the institutions', a formulation which only exacerbated the problem that the wider Europe agenda was intended to address.

The ENP sought to mediate between the ins and outs, as part of the EU's permanent negotiation of boundaries and interactions with neighbours (Whitman and Wolff 2010). With the mass accession of a number of post-communist countries, most of which had been part of the Soviet bloc or even of the Soviet Union itself, in 2004 and 2007, the character of this 'negotiation' changed, and it became less of an interactive process (to the degree that it ever was), and became more didactic. The specific manifestation of this new didacticism was the launching of the Eastern Partnership (EaP) in May 2009, an idea sponsored by some of Russia's most resolute critics in Poland and Sweden (Copsey and Pomorska 2014). Although tempered by Brussels, the EaP combined the normative and spatial challenge that the EU posed to its neighbours. The tension between the universalistic aspirations of the EU as a post-modern norm-based project and the physical manifestation of the EU as a territorially-based entity permanently negotiating its physical engagement with neighbours was exacerbated (Browning 2005).

Engagement deploys a range of traditional diplomatic and other instruments, accompanied by a dynamic of adaptation-based conditionality that tempers realist interactions. As the EU grew and embraced the post-communist region, its dualism became increasingly 
delineated to expose the tensions between norms and space. Both lost their original transformational impetus. The norms were tempered and modified as conditionality itself in certain circumstances became 'conditional', dependent on specific local conditions (this is the charge, for example, about the accession of Estonia and Latvia with a large number of predominantly Russian 'non-citizens') (Kochenov 2008). And when it came to space, instead of transcending the 'borderness' of borders, which it had achieved with such success among the original members of the European Economic Community (EEC), borders were back with a vengeance. But these were 'post-modern' borders, now manifested as the 'frontier' between the empire of good governance and all that was normatively progressive, and the dark and savage lands of corruption and neo-Sovietism on the other side. The new east European member states turned out to be much harsher pedagogues than the realist-inclined old Europeans (Mälksoo 2013, 158-9).

Not surprisingly, relations with Russia soured and an increasingly overt struggle for influence intensified in the so-called 'shared neighbourhood', the traditional borderlands between the two major zones of Europe in the intermarium between the Baltic and Black Seas (DeBardeleben 2008). For the EU, this meant that pragmatism threatened to undermine its normative idealism as hard choices had to be made when dealing with a new type of recalcitrant regimes. It had hitherto been mostly plain sailing for the EU, extending its influence to regions that welcomed the EU as the path to political and economic modernisation. The complexities of the Balkans were a foretaste of the problems to come, but for the first time in the intermarium the EU came up against a rival hegemonic enterprise. A new mode of engagement was called for, one more sensitive to ideational pluralism and developmental ambiguities. After all, the Soviet Union had also been a progressive combination of time and space, and had delivered a type of modernisation. The EU's model of normative superiority and transcendence of space could not but be ambivalently inserted into a region that had already experienced the ambiguities and contradictions of such a project. Contestation in the intermarium was thus far from purely geopolitical, and even its designation as civilisational is inadequate (Huntington 1993). The struggle is over developmental models, representations of the past, and above all, about didacticism and autonomy.

The crisis encompasses the geographical borderlands between the EU and Russia as well as broader understanding of the contemporary European order. Temporal and spatial configurations have come into conflict. The monism of the EU combines both dimensions. In terms of space, engagement with non-EU countries has been monological and pedagogical the engagement and learning has been entirely one way, with Europe's neighbours having to adapt to the EU on the latter's terms. The logic of European integration and the wider Europe agenda is hostile to difference, and instead assumes a uniform process of enlargement, however differentiated the actual integration mechanisms. This uniformity is imposed as the price to pay to take advantage of what the EU has to offer, above all an enormous market and a set of regulatory, political and human rights norms that offer the prospect for dynamic liberal capitalist development. The push for a more differentiated approach towards the eastern neighbourhood (see below) was belated recognition of the excessive monism of earlier policies.

The EU engages in a deeply transformative relationship with its neighbours, demanding acceptance of the subaltern relationship of pupil to the EU's teacher. The inevitable hierarchy proved unacceptable to Russia The EU's 'normative imperialism' under-estimated the specificities of the EaP region and the potential for conflict with Russia (Pänke, 2015). Critics argue that Russia's refusal to engage in the transformative process provoked the breakdown, whereas the question can be posed as one of autonomy, both in terms of political sovereignty and of historical experience. Member States may have resolved a range of historical problems within the format of the EU, but this does not automatically translate into solutions for a country as vast and complex as Russia. Incommensurate understandings of the challenges posed by 
contemporary temporality have shifted onto the plane of spatial confrontation in the borderlands. International relations were reduced to a form of depoliticised governmentality (Neumann and Sending, 2007).

The failure to establish a dialogue of difference between the actually existing components of Europe provoked the breakdown of 2014. The ascription of a certain nonEuropeanness to Russia - with Europe described in the monist terms outlined above - inhibited the instantiation of a dialogical relationship in which both the European self and the Russian other could have engaged in a mutual learning process (Neumann, 1999). The view that there is not much that the EU can learn from Russia is valid to the degree that learning is restricted to a narrow platform of normative and institutional interactions, whereas a broader learning agenda would include the problem of how multiple entities can create a fruitful relationship on the continent. For this a pan-continental greater Europe agenda complements the Brusselscentric wider European agenda. The beginning of any learning process is acknowledgment of the need to learn. Prozorov $(2016,183)$ argues that this requires the EU to accept the existence of a European political space broader than the space integrated (in whatever manner) by the EU, 'a space in which the EU interacts as an "international", rather than a "domestic" actor with other European actors, which, unlike the EU, are sovereign states, but no less equal to the EU in the common space of pluralistic interaction'. This would shift the basis of relations away from Russia's 'problematic status' in the framework of European integration towards a project where the 'logic of common European pluralism seeks to maintain Europe as a space of pluralistic interaction, in which commonality is ensured by the mutual recognition of legitimate difference and the relaxation of the rigid delimitation of ontopological identities' (Prozorov 2016, 184). This would be a common European home with many rooms but still recognisable as a single community.

\section{Towards political dialogism}

The logic of the transcendence of the Cold War accentuated the monological, and thus axiological, character of contemporary world and European politics. This entails a number of depoliticised and bureaucratised practices. In this era of mimetic politics, the form is preserved but the substance of what makes politics political has been lost. While liberalism suggests that rational debate between relatively equal subjectivities can lead to rational consensus, Schmitt (1996) asserted that the essence of the political was the creation of a 'we' in opposition to the 'other'. The friend-enemy relation is what fundamentally defines the political. This is seen at its sharpest in various forms of axiological politics. The counter-position to this axiological style of politics is political dialogism. It seeks to establish a space for autonomy and resistance to the dominance of the social forms of the hegemonic regime at the international and national levels, and seeks to give recognition to the political subjectivity of the 'other'. This is the 'agonistic pluralism' advanced by Mouffe (1993, pp. 1-8). Contemporary European politics is characterised by the tension between these two definitions of the political. In this debate, Schmittean realism is ranged alongside post-Cold War monistic liberalism, but is challenged by traditional versions of liberal pluralism. The historicism that was incorporated into hegemonic Atlanticism after 1989 encountered in Russia an anti-hegemonic politics of resistance.

The EU moved towards a more differentiated policy towards its Eastern neighbours following the Ukraine crisis, but this remains far from a genuine dialogical relationship. The fourth Eastern Partnership summit in Riga on 21-22 May 2015 focused on the principles of 'differentiation and inclusivity'. The Joint Declaration affirmed 'the sovereign right of each partner freely to choose the level of ambition and the goals to which it aspires in its relations with the European Union', and there was a new emphasis on 'differentiated relations between the EU and its six sovereign, independent partners' (EU Council 2015). The tone of the revised 
EU Global Strategy adopted by the European Council on 28 June 2016 dropped the language of partnership with Russia and instead a stern and didactic tone predominated (EU 2016). The Strategy declared that 'Principled pragmatism will guide our external action in the years ahead' (EU 2016, 8). There was less emphasis on the ENP, and instead the focus was on fostering the 'resilience' of neighbouring states accompanied by the assertion of the 'strategic autonomy' of the EU (EU 2016, 4), accompanied by a deeper partnership with NATO. None of this betokened a move away from the axiological style of politics, but represented no more than a 'smarter' monism.

The substance of a dialogical politics is the recognition of equal political subjectivity for political actors. In international affairs this means overcoming limited sovereignty regimes in favour of the recognition of multiple centres of civilisational and political identity. This is the multipolarity that has long been propounded by Russian leaders, and was argued for by Schmitt in his notion of the pluriverse (Schmitt 2006). Geopolitics is certainly fundamental to post-Cold War axiology, but dialogical politics entails a double movement: countering the logic of axiological politics in the international sphere accompanied by revalorisation of substantive political community in domestic matters. The two are profoundly inter-connected, and effectively part of a single process. Contemporary dialogical politics are inspired by a number of ideas and characterised by a number of practices.

The Enlightenment as a project is often considered to have an inherent monological dimension, countered according to some critics by the luxurious pluralism of postmodernity and postsecularity (Caputo 2001). At the heart of the 'monologue of the Enlightenment' is its antireligiosity, which in the end presents an eviscerated representation of individual freedom (Kyrlezhev 2008, 24). Hans-Georg Gadamer's (2004) explorations in 'philosophical hermeneutics', in particular the status of knowledge, had already criticised the attempt to reduce the study of the humanities to the methods of the natural sciences. Of greater importance for our purposes is his work on 'dialogue and dialectic' (Gadamer 1980), as well as essays on 'the relevance of the beautiful' (Gadamer 1986). His focus on particularity and specificity within a dynamic whole opens up the potential for value pluralism within the bounds of an expansive political order. Above all, Bakhtin's studies of cultural forms, knowledge and society provide an original approach to the relationship of the individual and society (Clark and Holquist 1984). Bakhtin's interpretation of the dialogical focuses on the way that humans use language, and he advanced a dialogical concept of its use. It is on this basis that Michael Holquist coined the term 'dialogism', a word that Bakhtin never used $(1990,15)$. Holquist notes Bakhtin's attraction to the neo-Kantian Marburg school, and in particular the works of Hermann Cohen, for its emphasis on unity and oneness; accompanied by his lifelong preoccupation with the problem of dialogue. The neo-Kantian concern with overcoming the duality between 'mind' and 'spirit' in Bakhtin's thinking took a distinctive turn:

In dialogism, the very capacity to have consciousness is based on otherness. This otherness is not merely a dialectical alienation on its way to a sublation that will endow it with a unifying identity in higher consciousness. On the contrary: in dialogism consciousness is otherness. More accurately, it is the differential relation between a center and all that is not that center (Holquist 1990, 18).

For our purposes, the political import is clear: inherent in dialogue is the constitution of distinct subjectivities, with a valance that is innate and not created by the relationship with the central other; although for Bakhtin the self is never an independent construct but 'dialogic', a relation (Holquist 1990, 19). Hence 'Dialogism is a form of architectonics, the general science of ordering parts into a whole. In other words, architectonics is the science of relations', a permanently dynamic set of ratios and proportions (Holquist 1990, 29). To put it simply, the self is to society 
what words are to language (Holquist 1990,31). The neo-Kantian element is clearly problematic, since it is one of the foundational well-springs for post-communist monism, yet in Bakhtin's conception oneness is far from reduction to singularity but assumes a pluralistic dynamic generating unity out of diversity.

In his studies of Dostoevsky, Bakhtin argues that dialogue is not a means to an end, but is the core of action itself. The variegated voices constitute a dialogical entity, which is very different from a dialectical relationship. As Bakhtin put it, 'Take a dialogue and remove the voices (the partitioning of voices), remove the intonations (emotional and individualizing ones), carve out abstract concepts and judgments from living words and responses, cram everything into one abstract consciousness - and that's how you get dialectics' (Bakhtin in Emerson and Holquist 1986, 147). Hwa Yol Jung, who cites the above text, comments on this as follows: 'Hegel's "theoreticism" and Marx's "ideologism" are equally dogmatic because they foreclose history as a movement, as an open future. The open-ended dialogics of difference foster the idea that a multiplicity of differences finds no ending' (Yol Jung 1998, 99). He ends his chapter with the pronouncement: 'Mikhail Bakhtin has come of age as a social and political thinker' (Yol Jung 1998, 107); and stresses 'The pinnacle of Bakhtin's heterotopia or dialogical body politics is the primacy of the singular Other in all relationships. ... It is this heterocentric idea that prompts Hans-George Gadamer ... to say that the heart of (dialogical) hermeneutics is the possibility that the Other might be right' (Yol Jung 1998, 108). Where teleological liberalism and historicist Marxism as the two great political organising principles of our age have clearly exhausted much of their potential to provide intelligibility to our world, let alone to provide an emancipatory and critical drive, dialogism emerges as a new 'ism' with creative scope to generate ideas about the substance of political community encompassing heteronomous political subjectivities and sovereignties. In other words, liberal pluralism is back on the agenda, even if takes 'post-liberal' forms. The challenge posed by Andrew Linklater (1998) to 'transform political community' can be addressed by the 'thick' practices of political dialogism.

\section{Conclusion}

The language of 'transitology' and 'Europeanisation' is imbued with an axiological mentality. Societies caught in the toils of accelerated transformation are by definition seen as incomplete and unformed, requiring a civilisational and didactic adaptation to norms generated elsewhere, and thus their political subjectivity is automatically treated as inferior. While Hayek had critiqued the idea of taxis (a social order made by design, accessible to human intelligence), to which he counterpoised the idea of cosmos (a spontaneously evolving and unplanned social order, not fully accessible to human intelligence), with the socialist projects for human amelioration, it is the post-communist creation of capitalist democracy that ended up being the most spectacular taxis of our time. The political subjectivity of other countries, such as Iran, which have long been engaged with coming to terms with modernity on the basis of civilizational autonomy, are denigrated for rather different reasons - above all their stubborn pursuit of their own form of modernity and the means to defend themselves. As far as Europe is concerned, it is Russia which continues to act as the collective repository for the collective violence, pedagogical aspirations and target of European values.

An exploration of the distinction between axiological and dialogical politics allows a more nuanced understanding of political processes today, at both the domestic and international level. The distinction between forms of rule, the forma imperii, and the mode of rule, forma regiminis, allows us to identify one of the most salient features of contemporary domestic and international politics, the intensification of axiological politics. The style of politics is as important as the formal institutional and normative framework. Even the most 'democratic' or 'liberal' government or opposition movement can engage in axiological politics; while an 
ostensibly authoritarian constitution can be managed in a relatively dialogical manner. This has become an issue of increasing concern in the comparative democratisation literature, above all through increased interest in 'quality of democracy' issues (for example, O'Donnell et al. 2004). Opposition to an authoritarian order is not in and of itself normatively able to transcend axiological practices, and tends to reinforce them in new forms. The Leninist wing of the Bolshevik Party is an extreme example of the application of axiological politics in both opposition and power. The repudiation of the communist order in 1989-1991 in the end became a counter-revolution rather than an anti-revolution. As is so often the case, the practices of the other against which the revolution was directed were reincorporated into the new ruling order. In the post-Cold War European case, options, variation and the agonistic pluralism of the political were suppressed in favour of a monist practice of enlargement rather than transformation. The post-communist settlement lost its emancipatory potential and reinforced the victory of one side at the expense of the other rather than transcending the logic of axiological politics in its entirety.

The self/other binary can take both axiological and dialogical forms. A range of mimetic methods are present in the former, including the classic process of self-constitution through the 'othering' of the outsider and the external threat. This process is as characteristic of hegemonic social formations as it is for subaltern states whose identity is protean and role in the world contested (cf. Morozov 2015). By contrast, the dialogical version of the self and differentiated other allows the re-insertion of the political in the framework of a new shared decentred normal. The political subjectivity of the other is not only acknowledged but also valued, as adding an element of normative diversity to the world or in domestic politics, which can help to establish a healthy environment for the growth and development of the self as much as the other. Instead, axiological processes came increasingly to the fore in relations between Russia and Europe. Although the EU invested considerable resources into the relationship, with talk of 'strategic partnership', 'common spaces' and 'partnership for modernisation', much of this assumed that the various mechanisms of 'external governance' would transform Russia from an alien other into some version of us. The politics of adaptation assumed an axiological inflexion. Even at its most benign, EU policy was imbued with a transformative mission based on the axiological belief that Russia's political subjectivity was somehow inappropriate and potentially pathological.

The self/other dynamic is constantly evolving, and in this article I have argued that classical approaches need to be supplemented by a focus on the status of the political subjectivity of the other. The ideology of 'normative power' and the politics of adaptation reinforced axiological practices and their attendant power hierarchies. Didactic, if not orientalist or dialectical, relations were restored, re-establishing the peripherality of Eastern Europe and the otherness of Russia. By contrast, the dialogical approach provides a way to theorise how new political communities can be established on the basis not just of reciprocity but of recognition of political equality. This is a permanent dynamic of open-ended interactions and an agonistic form of the political. Dialogism may not provide any ready-made solutions, but it provides a key to thinking about the mutual recognition that is essential to achieving the genuine transformation of European political community.

\section{References}

Bakhtin, M. M. 1986. Speech Genres and Other late Essays, in: C. Emerson and M. Holquist (eds). Austin Texas: University of Texas Press 
Browning, C. S. 2005. 'Westphalian, Imperial, Neomedieval: The Geopolitics of Europe and the Role of the North', in Christopher S. Browning (ed.), Remaking Europe in the Margins: Northern Europe after the Enlargements. Aldershot: Ashgate, 2005: 85-101

Brzezinski, Z. 1994. "The Premature Partnership". Foreign Affairs 73 (2): 67-82

Caputo, J. D. 2001. On Religion. London: Routledge

Carr, E.H. 2001 [1939]. The Twenty Years' Crisis, 1919-1939: An Introduction to the Study of International Relations. London: Palgrave

Chebankova, E. 2017. 'Ideas, Ideology and Intellectuals in Search of Russia's Political Future', Daedalus, 146 (2): 76-88

Clark, K. and M. Holquist. 1984., Mikhail Bakhtin. Cambridge, MA: The Belknap Press

Cohen, S. F. 2017. Why Cold War Again? How America Lost Post-Soviet Russia. London and New York: I. B. Tauris

Cooper, R. 2003. The Breaking of Nations: Order and Chaos in the Twenty-First Century. New York: Atlantic Monthly Press

Copsey, N. and K. Pomorska. 2014. "The Influence of Newer Member States in the European Union: The Case of Poland and the Eastern Partnership". Europe-Asia Studies 66 (3): 421443

DeBardeleben, J. 2008. The Boundaries of EU Enlargement: Finding a Place for Neighbours. Basingstoke: Palgrave Macmillan

Edkins, J. (ed.) 1999. Poststructuralism and International Relations: Bringing the Political Back In. London: Lynne Rienner

EU. 2016. Shared Vision: Common Action: A Stronger Europe. A Global Strategy for the European Union's Foreign and Security Policy. http://europa.eu/globalstrategy/en

EU Council. 2015. Joint Declaration of the Eastern Partnership Summit, Riga, 21-22 May 2015. http://www.consilium.europa.eu/en/meetings/international-summit/2015/05/21-22/.

Gadamer, H. 1980. Dialogue and Dialectic: Eight Hermeneutical Studies on Plato. New Haven, CT: Yale University Press

Gadamer, H. 1986. The Relevance of the Beautiful and Other Essays, trans. N. Walker, ed. R. Bernasconi. Cambridge: Cambridge University Press

Gadamer, H. 2004. Truth and Method, $2^{\text {nd }}$ rev. Edn, trans J. Weinsheimer and D. G. Marshall. New York: Crossroad

Goldgeier, J. and M. McFaul. 2003. Power and Purpose: US Policy Toward Russia after the Cold War. Washington, DC: Brookings Institution

Habermas, J. 1984. A Theory of Communicative Action, Vol. 1, Reason and the Rationalization of Society. London

Habermas, J. 1987. A Theory of Communicative Action, Vol. 2, Lifeworld and System: A Critique of Functionalist Reason. Cambridge: Polity

Haukkala, H. 2016. "A Perfect Storm; Or What Went Wrong and What Went Right for the EU in Ukraine". Europe-Asia Studies 68 (4): 653-664

Heartfield, J. 2013. The European Union and the End of Politics. London: Zero Books

Holquist, M. 1990. Dialogism: Bakhtin and his World. London: Routledge

Horsfield, D. 2017. Russia in the Wake of the Cold War: Perceptions and Prejudices. Lanham, MD: Lexington Books

Huntington, S.P. 1993. “The Clash of Civilizations?”. Foreign Affairs 72 (3): 23-49

Huntington, S.P. 1996. The Clash of Civilizations and the Remaking of World Order. New York: Simon \& Schuster

Kasparov, G. and M. Greengard. 2015. Winter is Coming: Why Vladimir Putin and the Enemies of the Free World Must be Stopped. London: Atlantic Books

Kazharski, A. and A. Makarychev. 2015. "Suturing the Neighborhood? Russia and the EU in Conflictual Intersubjectivity". Problems of Post-Communism 62(6): 328-339 
Kochenov, D. 2008. EU Enlargement and the Failure of Conditionality: Pre-Accession Conditionality in the Fields of Democracy and the Rule of Law. Alphen aan den Rijn: Kluwer Law International

Kyrlezhev, A. 2008. "The Postsecular Age: Religion and Culture Today". Religion, State and Society. 36 (1): 21-31

Laclau, E. 2005. On Populist Reason. London: Verso

Laclau, E. and C. Mouffe. 2001. Hegemony and Socialist Strategy. London: Verso

Legvold, R. 2016. Return to Cold War. Cambridge: Polity

Linklater, A. 1998. Transformation of Political Community: Ethical Foundations of the PostWestphalian Era. Cambridge: Polity

Mälksoo, M. 2013. "Decentring the West from Within: Estonian Discourses on Russian Democracy", in Morozov, V. (ed.), Decentring the West: The Idea of Democracy and the Struggle for Hegemony. Farnham: Ashgate: 157-173

Monaghan, A. 2015. A 'New Cold War'? Abusing History, Misunderstanding Russia. London: Chatham House Research Paper

Mouffe, M. 1993. The Return of the Political. London: Verso

Morozov, V. 2015. Russia's Postcolonial Identity: a Subaltern Empire in a Eurocentric World. London: Palgrave Macmillan

Neumann, I.B. 1999. Uses of the Other: The "East" in European Identity Formation. Minneapolis, MN: University of Minnesota Press

Neumann, I.B. and O.J. Sending. 2007. "The "International” as Governmentality". Millennium: Journal of International Studies 35 (3): 677-701

O’Donnell, G., J. Vargas Cullell and O.M. Iazzetta. 2004. The Quality of Democracy. Notre Dame, IN: University of Notre Dame Press

Pabst, A. 2016. "Brexit, Post-Liberalism, and the Politics of Paradox". Telos 176: 89-101

Pänke, J. 2015. “The Fallout of the EU's Normative Imperialism in the Eastern Neighborhood". Problems of Post-Communism 62(6): 350-363

Prodi, R. 2002. "A Wider Europe: A Proximity Policy as the Key to Stability", Brussels, 5-6 December 2002. http://europa.eu/rapid/press-release_SPEECH-02-619_en.htm

Prozorov, S. 2016. Understanding Conflict between Russia and the EU: The Limits of Integration. Basingstoke: Palgrave Macmillan

Ratzinger, J. and J.Habermas. 2007. The Dialectics of Secularization: On Reason and Religion

Foreword by Florian Schuller. San Francisco, CA: Ignatius Press

Rumelli, B. 2004. "Constructing Identity and Relating to Difference: Understanding the EU's Mode of Differentiation". Review of International Studies 30 (1): 24-47

Sakwa, R. 1998. "Konets epokhi revolyutsii: antirevolyutsionnye revolyutsii 1989-1991 godov" ("The End of the Age of Revolutions: The Anti-revolutions of 1989-1991"). Politicheskie Issledovaniya - Polis 5: 23-38

Sakwa, R. 2001. "The Age of Paradox: The Anti-revolutionary Revolutions of 1989-91”, in Donald, M. and T. Rees (eds), Reinterpreting Revolution in Twentieth-Century Europe. London: Macmillan: 159-176

Sakwa, R. 2013. "The Cold Peace: Russo-Western Relations as a Mimetic Cold War". Cambridge Review of International Affairs, 26(1): 203-224

Sakwa, R. 2016. Frontline Ukraine: Crisis in the Borderlands, updated paperback edition. London: I. B. Tauris

Sakwa, R. 2016. "Back to the Wall: Myths and Mistakes that Once Again Divide Europe". Russian Politics 1 (1): 1-26

Streeck, W. 2016. How Will Capitalism End? Essays on a Failing System. London: Verso

Schmitt, C. 1996. The Concept of the Political. London: University of Chicago Press 
Schmitt, C. 2006. The Nomos of the Earth in the International Law of the Jus Publicum Europaeum. Translated and annotated by G. L. Ulmen. New York: Telos Press Publishing Wæver, O. 1996. "European Security Identities". JCMS: Journal of Common Market Studies. 34 (1): 103-132

Whitman, R. and S. Wolff. Eds. 2010. The European Neighbourhood Policy in Perspective: Context, Implementation and Impact. Basingstoke: Palgrave Macmillan

Yol Jung, H. 1998. "Bakhtin's Dialogical Body Politics". In: Mayerfield Bell, M. and M. Gardiner. eds. Bakhtin and the Human Sciences: No Last Words. London: Sage: 95-111

Zielonka, J. 2007. Europe as Empire: The Nature of the Enlarged European Union. Oxford: Oxford University Press

Zielonka, J. 2008. "Europe as a Global Actor: Empire by Example?”. International Affairs 84 (3): 471-484

Zielonka, J. 2013. "Europe's New Civilizing Missions: The EU's Normative Power Discourse". Journal of Political Ideologies 18 (1): 35-55

Zwolski, K. 2016. 'Wider Europe, Greater Europe? David Mitrany on European Security Order', JCMS: Journal of Common Market Studies 55 (3): 645-661. 